Слабкий Г.О., Білак-Лук’янчук В.Й., Кручаниця В.В.

\title{
Медико-демографічні показники дитячого населення Закарпатської області як проблема громадського здоров'я регіону
}

\author{
ДВНЗ «Ужгородський національний університет», м. Ужгород, Україна \\ g.slabkiy@ukr.net, bilak.vika@gmail.com, 7krucha@gmail.com
}

Слабкий Г.А., Билак-Лукьянчук В.И., Кручаница В.В. Медико-демографические показатели детского населения Закарпатской области как проблема общественного здоровья региона ГВУЗ «Ужгородский национальный университет», г. Ужгород, Украина
Slabkyi G.O., Bilak-Lukianchuk V.I., Kruchanytsia V.V. Medical and demographic indicators of child population in Transcarpathian region as a problem of public health of the region

SU "Uzhhorod national university", Uzhhorod, Ukraine

\section{ВетуII}

Збереження і зміцнення здоров'я дітей є однією 3 актуальних проблем охорони здоров'я [1]. Рішення даної проблеми має високу соціальну значущість і входить у число найважливіших завдань держави, оскільки здоров'я дітей становить фундаментальну основу для формування громадського здоров'я, трудового потенціалу країни і є фактором національної безпеки [2,3]. Здоров'я дитячого населення визначається рядом факторів, серед яких провідними $є$ спосіб життя, спадковість, матеріальне і соціальне забезпечення сім’ї. За даними Глобальної стратегії ВОО3 з охорони здоров'я жінок i дітей визначено, що інвестиції в здоров'я дітей мають високу економічну доцільність і забезпечують найкращу гарантію наявності продуктивної робочої сили у майбутньому [4].

Тому формування i збереження здоров'я дітей України стає надзвичайно важливою справою, оскільки це - наше майбутнє і одне з головних джерел повноцінного життя, щастя, радості, успіху. Воно є не лише особистим надбанням людини, але й суспільним багатством, одним із найважливіших показників добробуту народу.
Мета роботи: дослідити та проаналізувати медико-демографічні показники дитячого населення Закарпатської області в динаміці 2014-2018 років з позиції системи громадського здоров'я.

\section{Матеріали та методи}

При виконанні дослідження використано статистичний метод та метод структурно-логічного аналізу. Матеріалами дослідження стали дані статистичної галузевої звітності по Закарпатській області за 2014, 2017 та 2018 роки [5-7].

\section{Результати дослідження та їх обговорення}

На початку дослідження були вивчені дані про кількість дитячого населення, яке проживає в області, його розподіл за місцем проживання (сільська місцевість, міста), показники народжуваності та смертності дітей у віці до року життя. Отримані результати наведено в табл. 1.

\section{Таблиця 1. Дані про дитяче населення, яке проживас в Закарпатській області} та його народжуваність і смертність у 2014, 2017 та 2018 рр.

\begin{tabular}{|c|c|c|c|c|c|}
\hline \multicolumn{2}{|l|}{ Показник } & 2014 & 2017 & 2018 & 2018 р. до 2014 р., \% \\
\hline \multicolumn{2}{|c|}{ Кількість дитячого населення, осіб } & 287889 & 292011 & 292303 & $+1,5$ \\
\hline \multirow{2}{*}{$\begin{array}{l}\text { Кількість дитячого населення } \\
\text { в сільській місцевості }\end{array}$} & абс. & 185090 & 186903 & 186421 & $+0,7$ \\
\hline & $\%$ & 64,3 & 64,0 & 63,8 & $-0,8$ \\
\hline \multirow{2}{*}{$\begin{array}{l}\text { Кількість дитячого населення } \\
\text { в містах }\end{array}$} & абс. & 102799 & 105108 & 105882 & $+0,8$ \\
\hline & $\%$ & 35,7 & 36,0 & 36,2 & $+0,8$ \\
\hline \multicolumn{2}{|c|}{ Народжуваність, \%о } & 14,8 & 12,7 & 11,6 & $-21,6$ \\
\hline \multicolumn{2}{|c|}{$\begin{array}{l}\text { Смертність дітей віком до } 1 \text { року життя, } \\
\text { на } 1000 \text { народжених живими }\end{array}$} & 9,0 & 10,4 & 11,4 & $+26,7$ \\
\hline
\end{tabular}


За роки дослідження кількість дитячого населення має тенденцію до збільшення (на 1,5\%), при цьому частка сільського дитячого населення має тенденцію до скорочення i складає $63,8 \%$, а частка дітей, які проживають в містах, має тенденцію до збільшення i складає $36,2 \%$.

Народжуваність в області скоротилася на 21,6\% і в 2018 році склала 11,6\%. При цьому показник народжуваності в розрізі адміністративних територій коливався від 9,23\% в Берегівському до 14,97\% в Перечинському районі. Гранична різниця показника становить 1,62 разів.

Смертність дітей віком до 1 року життя в розрахунку на 1000 народжених живими за роки дослідження збільшилася на $26,7 \%$ і склала 11,4 . В розрізі адміністративних територій даний показник коливався від 3,21 в Свалявському до 15,77 в Великоберезнянському районі. Гранична різниця показника становить 4,91 разів.

Далі вивчалися показники захворюваності дитячого населення Закарпатської області в розрізі адміністративних територій за період 2014-2018 pp. Отримані результати наведено в табл. 2.

За період дослідження показники захворюваності дитячого населення Закарпатської області мають тенденцію до скорочення (на 7,8\%) з рівнем 883,98 на 1000 дітей. Скорочення показника зареєстровано на 9 (64,3\%) адміністративних територіях 3 найбільшим рівнем скорочення в Мукачівському районі (33,0\%). Збільшення показника зареєстровано на 5 (35,7\%) адміністративних територіях 3 найвищим рівнем збільшення на території Великоберезнянського району $(33,1 \%)$.
В розрізі адміністративних територій реєструється статистично значуща різниця вказаного показника. Так, в 2018 році найнижчий рівень захворюваності дитячого населення зареєстровано в Іршавському районі $(441,02$ на 1000 дітей), а найвищий рівень - в м. Ужгород $(1305,63)$. Гранична різниця показника в розрізі адміністративних територій склала 2,96 разів.

Наступним кроком дослідження було вивчення динаміки показників поширеності хвороб серед дитячого населення Закарпатської області. Отримані результати наведено в табл. 3.

Показники поширеності хвороб серед дитячого населення Закарпатської області за роки дослідження мають тенденцію до скорочення (на - 4,8\%) 3 рівнем 1269,51 на 1000 дітей. Як скорочення, так і збільшення даного показника зареєстровано на 7 (50,0\%) адміністративних територіях області. Найбільший рівень скорочення показника зареєстровано в Воловецькому районі $(41,4 \%)$, а зростання показника зареєстровано на території Хустського району (47,3\%).

В розрізі адміністративних територій реєструється статистично значуща різниця вказаного показника. Так, в 2018 році найвищий рівень поширеності хвороб серед дитячого населення (1841,15 на 1000 дітей) зареєстровано на території Хустського району, а найнижчий $(804,24)$ на території Воловецького району. Гранична різниця показника в розрізі адміністративних територій склала 2,29 разів.

Для досягнення мети дослідження далі вивчалися показники захворюваності дітей Закарпаття за класами хвороб згідно МКХ-Х та відповідної поширеності хвороб серед дітей регіону. Дані наведені в табл. 4

Таблиця 2. Показники захворюваності дитячого населення Закарпатської області (на 1000 дітей), 2014, 2017, 2018 pp.

\begin{tabular}{|c|c|c|c|c|}
\hline \multirow{2}{*}{ Найменування } & \multicolumn{3}{|c|}{ На 1000 дітей } & \multirow{2}{*}{2018 р. до 2014 р., \% } \\
\hline & 2014 & 2017 & 2018 & \\
\hline Закарпатська область & 959,11 & 887,85 & 883,98 & $-7,8$ \\
\hline Берегівський район & 1139,79 & 1223,78 & 1198,43 & $+5,1$ \\
\hline Великоберезнянський район & 723,76 & 769,52 & 963,36 & $+33,1$ \\
\hline Виноградівський район & 1115,23 & 1073,05 & 1026,33 & $-8,0$ \\
\hline Воловецький район & 1023,26 & 780,47 & 797,40 & $-22,1$ \\
\hline Іршавський район & 602,97 & 498,69 & 441,02 & $-26,9$ \\
\hline Міжгірський район & 780,54 & 877,51 & 980,75 & $+25,7$ \\
\hline Мукачівський район & 1144,28 & 834,74 & 766,52 & $-33,0$ \\
\hline Перечинський район & 874,62 & 859,66 & 649,64 & $-25,7$ \\
\hline Рахівський район & 1069,40 & 1002,74 & 988,51 & $-7,6$ \\
\hline Свалявський район & 899,99 & 887,39 & 889,25 & $-1,2$ \\
\hline Тячівський район & 686,61 & 629,44 & 711,13 & $+3,6$ \\
\hline Ужгородський район & 874,20 & 883,44 & 1005,60 & $+15,0$ \\
\hline Хустський район & 878,63 & 861,87 & 861,29 & $-2,0$ \\
\hline м. Ужгород & 1415,94 & 1377,12 & 1305,63 & $-7,8$ \\
\hline
\end{tabular}


Таблиця 3. Показники поширеності хвороб серед дитячого населення Закарпатської області (на 1000 дітей), 2014, 2017, 2018 pp.

\begin{tabular}{|c|c|c|c|c|}
\hline \multirow{2}{*}{ Найменування } & \multicolumn{3}{|c|}{ На 1000 дітей } & \multirow{2}{*}{2018 р. до 2014 р., \% } \\
\hline & 2014 & 2017 & 2018 & \\
\hline Закарпатська область & 1334,10 & 1265,11 & 1269,51 & $-4,8$ \\
\hline Берегівський район & 1401,12 & 1506,77 & 1486,14 & $+6,0$ \\
\hline Великоберезнянський район & 1047,78 & 1110,46 & 1306,74 & $+24,7$ \\
\hline Виноградівський район & 1483,51 & 1435,74 & 1384,94 & $-6,6$ \\
\hline Воловецький район & 1371,80 & 1393,85 & 804,24 & $-41,4$ \\
\hline Іршавський район & 989,12 & 883,06 & 1345,79 & $+36,1$ \\
\hline Міжгірський район & 1079,19 & 1223,31 & 1245,01 & $+15,4$ \\
\hline Мукачівський район & 1559,84 & 1263,68 & 937,04 & $-39,9$ \\
\hline Перечинський район & 1176,94 & 1143,63 & 1302,68 & $+10,8$ \\
\hline Рахівський район & 1433,27 & 1328,16 & 1234,38 & $-13,9$ \\
\hline Свалявський район & 1240,63 & 1225,61 & 1046,96 & $-15,6$ \\
\hline Тячівський район & 1031,53 & 944,88 & 1478,25 & $+43,4$ \\
\hline Ужгородський район & 1266,30 & 1300,72 & 1223,67 & $-3,4$ \\
\hline Хустський район & 1249,88 & 1223,39 & 1841,15 & $+47,3$ \\
\hline м. Ужгород & 1959,37 & 1923,33 & 1475,39 & $-24,7$ \\
\hline
\end{tabular}

Таблиця 4. Показники захворюваності дитячого населення Закарпатської області та поширеності серед нього хвороб за класами хворорб (МКХ-Х) (на 1000 дітей), 2014, 2017, 2018 рр.

\begin{tabular}{|c|c|c|c|c|c|c|}
\hline \multirow{2}{*}{ Найменування } & \multicolumn{3}{|c|}{ Поширеність } & \multicolumn{3}{|c|}{ Захворюваність } \\
\hline & 2014 & 2017 & 2018 & 2014 & 2017 & 2018 \\
\hline Усі хвороби & 1334,10 & 1265,11 & 1269,51 & 959,11 & 887,85 & 883,98 \\
\hline Деякі інфекційні та паразитарні хвороби & 36,27 & 30,76 & 34,79 & 30,59 & 25,89 & 30,09 \\
\hline Новоутворення & 10,82 & 10,70 & 10,35 & 3,34 & 3,48 & 2,76 \\
\hline $\begin{array}{l}\text { Хвороби крові, кровотворних органів та окремі } \\
\text { порушення із залученням імунного механізму }\end{array}$ & 49,99 & 48,10 & 46,47 & 21,93 & 19,44 & 18,52 \\
\hline $\begin{array}{l}\text { Хвороби ендокринної системи, розлади } \\
\text { харчування, порушення обміну речовин }\end{array}$ & 99,87 & 96,47 & 91,39 & 27,69 & 23,62 & 21,55 \\
\hline Розлади психіки і поведінки & 21,50 & 18,78 & 18,00 & 2,89 & 2,28 & 2,13 \\
\hline Хвороби нервової системи & 44,44 & 44,64 & 42,43 & 18,28 & 17,64 & 16,17 \\
\hline Хвороби ока та придаткового апарату & 73,51 & 72,52 & 73,73 & 39,74 & 35,62 & 35,51 \\
\hline Хвороби вуха та соскоподібного відростка & 34,54 & 31,55 & 33,89 & 30,67 & 27,28 & 30,12 \\
\hline Хвороби системи кровообігу & 25,00 & 21,47 & 22,91 & 6,62 & 4,57 & 3,95 \\
\hline Хвороби органів дихання & 623,32 & 587,75 & 596,33 & 573,13 & 536,66 & 536,02 \\
\hline Хвороби органів травлення & 92,52 & 89,41 & 87,83 & 57,80 & 58,93 & 58,17 \\
\hline Хвороби шкіри та підшкірної клітковини & 70,76 & 68,90 & 67,73 & 58,24 & 53,50 & 52,00 \\
\hline $\begin{array}{l}\text { Хвороби кістково-м'язової системи та сполучної } \\
\text { тканини }\end{array}$ & 42,11 & 41,35 & 43,60 & 16,65 & 14,00 & 13,52 \\
\hline Хвороби сечостатевої системи & 26,21 & 25,76 & 25,27 & 14,77 & 14,04 & 13,90 \\
\hline $\begin{array}{l}\text { Окремі стани, що виникають в перинатальному } \\
\text { періоді }\end{array}$ & 8,16 & 6,37 & 4,71 & 8,05 & 6,37 & 4,71 \\
\hline $\begin{array}{l}\text { Уроджені аномалії (вади розвитку), деформації } \\
\text { i хромосомні порушення }\end{array}$ & 28,35 & 27,71 & 26,45 & 4,42 & 4,10 & 3,24 \\
\hline $\begin{array}{l}\text { Симптоми, ознаки та відхилення від норми, } \\
\text { що виявлені під час лабораторних та клінічних } \\
\text { досліджень, не класифіковані в інших рубриках }\end{array}$ & 1,66 & 1,88 & 1,35 & 1,40 & 1,61 & 1,09 \\
\hline $\begin{array}{l}\text { Травми, отруєння та деякі інші наслідки дії } \\
\text { зовнішніх причин }\end{array}$ & 43,77 & 40,28 & 41,41 & 41,83 & 38,28 & 39,82 \\
\hline
\end{tabular}


За роки дослідження структура як захворюваності дітей Закарпаття, так і поширеності серед них хвороб практично не змінилися. Статистично незначущі зміни зареєстровані тільки за рівнями показників.

В показниках захворюваності дітей за класами хвороб провідні місця займають наступні класи хвороб: хвороби органів дихання - 3 рівнем 536,02 на 1000 дітей, хвороби органів травлення - 3 рівнем 58,17 , хвороби шкіри та підшкірної клітковини - 52,00, травми, отруєння та деякі інші наслідки дії зовнішніх причин з рівнем 39,82. Зареєстровані високі рівні захворюваності дітей на деякі інфекційні та паразитарні хвороби - 30,09, хвороби вуха та соскоподібного відростка $(30,12)$ та хвороби ендокринної системи, розлади харчування, порушення обміну речовин $(21,55)$. В 2014 році в області було зареєстровано 308 випадків вагітності дівчат у віці до 18 років, а у 2018 році їх кількість скоротилася до 201 випадку.

В показниках поширеності хвороб серед дітей за класами хвороб провідні місця займають наступні класи хвороб: хвороби органів дихання з рівнем 596,33 на 1000 дітей, хвороби ендокринної системи, розлади харчування, порушення обміну речовин - 3 рівнем 91,39, хвороби органів травлення - 3 рівнем 87,83, хвороби ока та придаткового апарату - 3 рівнем 73,73. В плані громадського здоров'я звертає на себе увагу високий рівень поширеності серед дітей хвороб на наступними класами: травми, отруєння та деякі інші наслідки дії зовнішніх причин - 3 рівнем 41,41, деякі інфекційні та паразитарні хвороби - 3 рівнем 34,79 , розлади психіки i поведінки - 3 рівнем 18,00 , хвороби кістково-м'язової системи та сполучної тканини - 3 рівнем 43,60, хвороби вуха та соскоподібного відростка - 3 рівнем 33,89 , новоутворення - 3 рівнем 10,35 наявність яких призводить до зниження якості життя дітей.

Перспективи подальших досліджень пов'язані 3 вивченням впливу наявних хронічних хвороб у дітей на якість їх життя.

\section{Висновки}

В ході дослідження встановлено, що за період дослідження в області зареєстрована тенденція до збільшення кількості дитячого населення (на 1,5\%) до 292303 осіб, при цьому частка сільського дитячого населення складає $63,8 \%$, а частка дітей, які проживають в містах, складає $36,2 \%$.
Народжуваність в області скоротилася на 21,6\% і в 2018 році склала $11,6 \%$. Смертність дітей віком до 1 року життя в розрахунку на 1000 народжених живими за роки дослідження збільшилася на 26,7\% і склала 11,4 .

За період дослідження показники захворюваності дитячого населення Закарпатської області мають тенденцію до скорочення (на 7,8\%) з рівнем 883,98 на 1000 дітей. Скорочення показника зареєстровано на 9 (64,3\%) адміністративних територіях 3 найбільшим рівнем скорочення в Мукачівському районі (33,0\%). Збільшення показника зареєстровано на 5 (35,7\%) адміністративних територіях 3 найвищим рівнем збільшення на території Великоберезнянського району $(33,1 \%)$. В показниках захворюваності дітей за класами хвороб провідні місця займають наступні класи хвороб: хвороби органів дихання 3 рівнем 536,02 на 1000 дітей, хвороби органів травлення 3 рівнем 58,17, хвороби шкіри та підшкірної клітковини 52,00, травми, отруєння та деякі інші наслідки дії зовнішніх причин - 3 рівнем 39,82. Зареєстровані високі рівні захворюваності дітей на деякі інфекційні та паразитарні хвороби $(30,09)$, хвороби вуха та соскоподібного відростка - $(30,12)$ та хвороби ендокринної системи, розлади харчування, порушення обміну речовин - $(21,55)$. В 2014 році в області було зареєстровано 308 випадків вагітності дівчат у віці до 18 років, а у 2018 році їх кількість скоротилася до 201 випадку.

Показники поширеності хвороб серед дитячого населення Закарпатської області за роки дослідження мають тенденцію до скорочення (на - 4,8\%) з рівнем 1269,51 на 1000 дітей. Як скорочення, так і збільшення даного показника зареєстровано на 7 (50,0\%) адміністративних територіях області. Найбільший рівень скорочення показника зареєстровано в Воловецькому районі $(41,4 \%)$, а зростання показника зареєстровано на території Хустського району $(47,3 \%)$. В показниках поширеності хвороб серед дітей за класами хвороб провідні місця займають наступні класи хвороб: хвороби органів дихання з рівнем 596,33 на 1000 дітей, хвороби ендокринної системи, розлади харчування, порушення обміну речовин - 3 рівнем 91,39, хвороби органів травлення - 3 рівнем 87,83, хвороби ока та придаткового апарату - $з$ рівнем 73,73, травми, отруєння та деякі інші наслідки дії зовнішніх причин - 3 рівнем 41,41 .

Встановлено, що в розрізі адміністративних територій області показники захворюваності дітей та поширеності серед них хвороб мають статистично значущі відмінності.

\section{Література}

1. Шафранський ВВ, редактор. Щорічна доповідь про стан здоров’я населення, санітарно-епідемічну ситуацію та результати діяльності системи охорони здоров’я України. 2015 рік. МОЗ України, ДУ «УІСД МОЗ України». Київ; 2016.452 с.

2. Дудіна ОО. Досягнення, проблеми та шляхи вирішення питань в охороні здоров’я матерів і дітей. Результати діяльності галузі охорони здоров'я: 2012 рік. Київ; 2013:37-51.

3. Жилка НЯ, Слабкий ГО. Реалізація державної політики щодо здоров’я дітей у співпраці з міжнародними проектами (аналітичний огляд наукової літератури). Економіка і право охорони здоров'я. 2016;1(3):53-60. 
4. Глобальная стратегия охраны здоровья женщин, детей и подростков (2016-2030 гг.). Выживать процветать менять. Доступно 3: https://www.who.int/maternal_child_adolescent/documents/women-deliver-global-strategy/ru.

5. Мережа закладів та основні показники діяльності системи охорони здоров’я Закарпатської області за 2014 рік. Закарпатський обласний медичний інформаційно-аналітичний центр. Ужгород; 2015.110 с.

6. Мережа закладів та основні показники діяльності системи охорони здоров’я Закарпатської області за 2017 рік. Закарпатський обласний медичний інформаційно-аналітичний центр. Ужгород; 2018.144 с.

7. Мережа закладів та основні показники діяльності системи охорони здоров'я Закарпатської області за 2018 рік. Закарпатський обласний медичний інформаційно-аналітичний центр. Ужгород; 2019.152 с.

\section{References}

1. Shafranskyi VV, redaktor. Shchorichna dopovid pro stan zdorovia naselennia, sanitarno-epidemichnu sytuatsiiu ta rezultaty diialnosti systemy okhorony zdorovia Ukrainy. 2015 rik. MOZ Ukrainy, DU «UISD MOZ Ukrainy». Kyiv; 2016.452 s.

2. Dudina OO. Dosiahnennia, problemy ta shliakhy vyrishennia pytan v okhoroni zdorovia materiv i ditei. Rezultaty diialnosti haluzi okhorony zdorovia: 2012 rik. Kyiv; 2013:37-51.

3. Zhylka NIa, Slabkyi HO. Realizatsiia derzhavnoi polityky shchodo zdorovia ditei u spivpratsi z mizhnarodnymy proektamy (analitychnyi ohliad naukovoi literatury). Ekonomika i pravo okhorony zdorovia. 2016;1(3):53-60.

4. Global'naja strategija ohrany zdorov'ja zhenshhin, detej i podrostkov (2016-2030 gg.). Vyzhivat' procvetat' menjat'. Dostupno z: https://www.who.int/maternal_child_adolescent/documents/women-deliver-global-strategy/ru/

5. Merezha zakladiv ta osnovni pokaznyky diialnosti systemy okhorony zdorovia Zakarpatskoi oblasti za 2014 rik. Zakarpatskyi oblasnyi medychnyi informatsiino-analitychnyi tsentr. Uzhhorod; $2015.110 \mathrm{~s}$.

6. Merezha zakladiv ta osnovni pokaznyky diialnosti systemy okhorony zdorovia Zakarpatskoi oblasti za 2017 rik. Zakarpatskyi oblasnyi medychnyi informatsiino-analitychnyi tsentr. Uzhhorod; 2018.144 s.

7. Merezha zakladiv ta osnovni pokaznyky diialnosti systemy okhorony zdorovia Zakarpatskoi oblasti za 2018 rik. Zakarpatskyi oblasnyi medychnyi informatsiino-analitychnyi tsentr. Uzhhorod; $2019.152 \mathrm{~s}$.

Дата надходження рукопису до редакції: 06.09.2019 p. області.

Мета роботи: дослідити та проаналізувати медико-демографічні показники дитячого населення Закарпатської

Матеріали та методи. При виконанні дослідження використано статистичний метод та метод структурнологічного аналізу. Матеріалами дослідження стали дані статистичної галузевої звітності по Закарпатській області за 2014, 2017 та 2018 роки.

Результати та їх обговорення. В області проживає 292303 дітей, що складає 23,29\% від загальної кількості жителів регіону. При цьому народжуваність скоротилася на 21,6\% і в склала 11,6\%о, а смертність дітей віком до 1 року життя в розрахунку на 1000 народжених живими збільшилася на 26,7\% і склала 11,4\%о.

Показники захворюваності дитячого населення мають тенденцію до скорочення (на 7,8\%) з рівнем 883,98 на 1000 дітей та провідними місцями наступних класів хвороб: хвороби органів дихання $(536,02)$, хвороби органів травлення $(58,17)$, хвороби шкіри та підшкірної клітковини $(52,00)$, травми, отруєння та деякі інші наслідки дії зовнішніх причин $(39,82)$, деякі інфекційні та паразитарні хвороби $(30,09)$.

Показники поширеності хвороб серед дитячого населення мають тенденцію до скорочення (на - 4,8\%) 3 рівнем 1269,51 на 1000 дітей та провідними місцями наступних класів хвороб: хвороби органів дихання (596,33), хвороби ендокринної системи, розлади харчування, порушення обміну речовин $(91,39)$, хвороби органів травлення $(87,83)$, хвороби ока та придаткового апарату $(73,73)$, травми, отруєння та деякі інші наслідки дії зовнішніх причин $(41,41)$.

Висновки: медико-демографічні показники дитячого населення для системи громадського здоров'я мають значення в плані профілактики хвороб та забезпечення хворим дітям якість життя відповідного рівня.

Ключові слова: Закарпатська область, діти, народжуваність, захворюваність, поширеність хвороб.

Цель работы: исследовать и проанализировать медико-демографические показатели детского населения Закарпатской области.

Материалы и методы. При выполнении исследования использованы статистический метод и метод структурнологического анализа. Материалами исследования стали данные статистической отраслевой отчетности по Закарпатской области за 2014, 2017 и 2018 годы.

Результаты и их обсуждение. В области проживает 292303 детей, что составляет 23,29\% от общего количества жителей региона. При этом рождаемость сократилась на 21,6\% и в составила 11,6\%, а смертность детей до 1 года жизни в расчете на 1000 родившихся живыми увеличилась на 26,7\% и составила 11,4\%.

Показатели заболеваемости детского населения имеют тенденцию к сокращению (на 7,8\%) с уровнем 883,98 на 1000 детей и ведущими местами следующих классов болезней: болезни органов дыхания $(536,02)$, болезни органов 
пищеварения $(58,17)$, болезни кожи и подкожной клетчатки $(52,00)$, травмы, отравления и некоторые другие последствия воздействия внешних причин $(39,82)$, некоторые инфекционные и паразитарные болезни $(30,09)$.

Показатели распространенности болезней среди детского населения имеют тенденцию к сокращению (на - 4,8\%) с уровнем 1269,51 на 1000 детей и ведущими местами следующих классов болезней: болезни органов дыхания (596,33), болезни эндокринной системы, расстройства питания, нарушения обмена веществ $(91,39)$, болезни органов пищеварения (87,83), болезни глаз и придаточного аппарата $(73,73)$, травмы, отравления и некоторые другие последствия воздействия внешних причин $(41,41)$.

Выводы: медико-демографические показатели детского населения для системы общественного здоровья имеют значение в плане профилактики болезней и обеспечения больным детям качества жизни соответствующего уровня.

Ключевые слова: Закарпатская область, дети, рождаемость, заболеваемость, распространенность болезней.

The purpose of the work is to study and analyze medical and demographic indicators of the child population of Transcarpathian region.

Materials and methods. The statistical method and the method of structural-logical analysis were used in the study. The data of statistical sectoral reports on Transcarpathian region for 2014, 2017 and 2018 constituted the basis for the study.

Results and their discussion. There are 292303 children in the region, which is $23.29 \%$ of the total population of the region. The birth rate decreased by $21.6 \%$ and amounted to $11.6 \%$, and the death rate of children under 1 year of age per 1000 live births increased by $26.7 \%$ and amounted to $11.4 \%$.

Morbidity rates of child population tend to decrease (by $7.8 \%$ ) with the level of 883.98 per 1000 children. The leading places of disease classes are the following: respiratory diseases (536.02), digestive diseases (58.17), diseases of skin and subcutaneous tissue (52.00), trauma, poisoning and some other effects of external causes (39.82), some infectious and parasitic diseases (30.09).

The prevalence rates of diseases in child population tend to decrease (by - 4.8\%) with the level of 1269.51 per 1000 children. The leading places of disease classes are the following: respiratory diseases (596.33), endocrine diseases, eating disorders, metabolic disorders (91.39), diseases of digestive system (87.83), diseases of the eye and ocular adnexa (73.73), trauma, poisoning and some other consequences of external causes (41.41).

Conclusions: medical and demographic indicators of child population for the public health system are important in terms of disease prevention and provision of appropriate quality of life for sick children.

Key words: Transcarpathian region, children, birth rate, morbidity, prevalence of diseases.

Конфлікт інтересів: відсутній.

Conflicts of interest: authors have no conflicts of interest to declare.

\section{Відомоісті про авторів}

Слабкий Геннадій Олексійович - доктор медичних наук, професор, завідувач кафедри наук про здоров’я ДВНЗ «Ужгородський національний університет»; м. Ужгород, пл. Народна, 3.

+380(50) 171-16-48, g.slabkiy@ukr.net.

Білак-Лук'янчук Вікторія Йосипівна - кандидат медичних наук, доцент кафедри наук про здоров'я ДВНЗ «Ужгородський національний університет»; м. Ужгород, пл. Народна, 3.

+380 (50) 597-05-99, bilak.vika@gmail.com.

Кручаниця Василь Васильович - кандидат медичних наук, доцент кафедри наук про здоров’я ДВНЗ «Ужгородський національний університет»; м. Ужгород, пл. Народна, 3.

+380 (50) 270-40-00, 7krucha@gmail.com. 